medRxiv preprint doi: https://doi.org/10.1101/2021.09.30.21264337; this version posted October 3, 2021. The copyright holder for this preprint (which was not certified by peer review) is the author/funder, who has granted medRxiv a license to display the preprint in

It is made available under a CC-BY-ND 4.0 International license.

\title{
Risk-benefit analysis of the AstraZeneca COVID-19 vaccine in Australia using a Bayesian network modelling framework
}

\author{
Authors: \\ Colleen L Lau ${ }^{a^{*}}$, Helen J Mayfield ${ }^{\mathrm{a}}$, Jane E Sinclair ${ }^{\mathrm{b}}$, Samuel J Brown ${ }^{\mathrm{b}}$, Michael Waller ${ }^{\mathrm{a}}$, Anoop K \\ Enjeti $^{\mathrm{c}}$, Andrew Baird ${ }^{\mathrm{d}}$, Kirsty Short ${ }^{\mathrm{b}}$, Kerrie Mengersen ${ }^{\mathrm{e}}$, John Litt ${ }^{\mathrm{f}, \mathrm{g}}$ \\ ${ }^{a}$ School of Public Health, Faculty of Medicine, The University of Queensland, Brisbane, Queensland, \\ Australia \\ ${ }^{\mathrm{b}}$ School of Chemistry and Molecular Biosciences, Faculty of Science, The University of Queensland, \\ Brisbane, Australia. \\ ${ }^{\mathrm{c}}$ School Of Medicine and Public Health, University of Newcastle, Callaghan, NSW; Calvary Mater \\ Newcastle Hospital ,Waratah and NSW Health Pathology John Hunter Hospital, New Lambton \\ Heights, NSW \\ d St Kilda Medical Group, St Kilda, Victoria, Australia \\ e School of Mathematical Sciences, Faculty of Science, Queensland University of Technology, \\ Brisbane, Queensland, Australia \\ ${ }^{\mathrm{f}}$ Discipline of General Practice, College of Medicine and Public Health, Flinders University, \\ Adelaide, Australia. \\ ${ }^{\mathrm{g}}$ Scientific Advisory Committee, Immunisation Coalition, Melbourne, Victoria, Australia

\section{*Corresponding author} \\ Prof Colleen Lau \\ School of Public Health, Faculty of Medicine, \\ The University of Queensland \\ 288 Herston Rd, Herston, \\ Brisbane, Queensland 4006, Australia \\ Email: colleen.lau@uq.edu.au
}

\begin{abstract}
Thrombosis and Thromobocytopenia Syndrome (TTS) has been associated with the AstraZencea (AZ) COVID-19 vaccine. Australia has reported low TTS incidence of $<3 / 100,000$ after the first dose, with case fatality rate (CFR) of 5-6\%. Risk-benefit analysis of vaccination has been challenging because of rapidly evolving data, changing levels of transmission, and age-specific variation in rates of TTS, COVID-19, and CFR. We aim to optimise risk-benefit analysis by developing a model that enables inputs to be updated rapidly as evidence evolves. A Bayesian network was used to integrate local and international data, government reports, published literature and expert opinion. The model estimates probabilities of outcomes under different scenarios of age, sex, low $/ \mathrm{medium} / \mathrm{high}$ transmission $(0.05 \% / 0.45 \% / 5.76 \%$ of population infected over 6 months), SARS-CoV-2 variant, vaccine doses, and vaccine effectiveness. We used the model to compare estimated deaths from vaccine-associated TTS with i) COVID-19 deaths prevented under different scenarios, and ii) deaths from COVID-19 related atypical severe blood clots (cerebral venous sinus thrombosis \& portal vein thrombosis). For a million people aged $\geq 70$ years where $70 \%$ received first dose and $35 \%$ received two doses, our model estimated $<1$ death from TTS, 25 deaths prevented under low transmission, and $>3000$ deaths prevented under high transmission. Risks versus benefits varied significantly between age groups and transmission levels. Under high transmission, deaths prevented by AZ vaccine far exceed deaths from TTS (by 8 to $>4500$ times depending on age). Probability of dying from COVID-related atypical severe blood clots was 58-126 times higher (depending on age and sex) than dying from TTS. To our knowledge, this is the first example of the use of Bayesian networks for risk-benefit analysis for a COVID-19 vaccine. The model can be rapidly updated to incorporate new data adapted for other countries extended to other outcomes (e.g., severe disease), or used for other vaccines.
\end{abstract}


medRxiv preprint doi: https://doi.org/10.1101/2021.09.30.21264337; this version posted October 3, 2021. The copyright holder for this preprint (which was not certified by peer review) is the author/funder, who has granted medRxiv a license to display the preprint in It is made available under a CC-BY-ND 4.0 International license.

56 Keywords: SARS-CoV-2, vaccination, adverse events, thrombosis/thrombocytopenia syndrome,

57 Bayesian networks, model

60 Author contributions:

61 Conception and design: JL, AB, KRS, CLL, HJM, KM

62 Acquisition of data: JL, AB, KRS, CLL, HJM, JES, SJB, AKE

63 Analysis and interpretation: CLL, HJM, KM, JL, JES, SJB, MW

64 Drafting the article: CLL

65 Revising article for important intellectual content: All authors

66 Final approval of submitted version: All authors

67

68

69

HIGHLIGHTS

- $\mathrm{AZ}$ vaccination risk-benefit analysis must consider age/community transmission level

- $\mathrm{AZ}$ vaccine benefits far outweigh risks in older age groups and during high transmission

- AZ vaccine-associated TTS lower fatality than COVID-related atypical blood clots

- Bayesian networks utility for risk-benefit analysis of rapidly evolving situations

- BNs allow integrating multiple data sources when large datasets are not available

75

76 
medRxiv preprint doi: https://doi.org/10.1101/2021.09.30.21264337; this version posted October 3, 2021. The copyright holder for this preprint (which was not certified by peer review) is the author/funder, who has granted medRxiv a license to display the preprint in It is made available under a CC-BY-ND 4.0 International license .

84

85

\section{INTRODUCTION}

The AstraZeneca ChAdOx1 (AZD1222) COVID-19 vaccine (AZ vaccine) has been widely used globally, with one billion doses released in over 170 countries by August 2021 [1]. The vaccine is highly effective against symptomatic infection, serious illness and death from COVID-19 [2-4]. In March 2021, reports of AZ vaccine-associated Thrombosis with Thrombocytopenia Syndrome (TTS) began emerging from multiple countries, including Norway [5], Canada [6], the U.K. [7], and Australia [8], and appeared to be more common in younger age groups [8]. Although the incidence of TTS was very low ( $<3 / 100,000$ first doses in any age group in Australia), initial reports of high case fatality rates (CFR) (44\% in Germany [9] and 18\% in United Kingdom [7]) prompted some countries to recommend alternative COVID-19 vaccines in younger persons.

In Australia, a change in recommendation was made in April 2021 to preference the Pfizer/BioNTech (BNT162b2) COVID-19 vaccine over the AZ vaccine in those aged $<50$ years [10]. In June 2021, after the death of a 52-year-old woman, the recommendation was revised to preference the Pfizer vaccine over the AZ vaccine in those aged $<60$ years $[11,12]$. The AZ vaccine-associated TTS cases and deaths received significant media attention in Australia, resulting in increased vaccine reluctance, and uncertainty amongst the public and clinicians about risks versus benefits of vaccination [13]. The only other COVID-19 vaccine available in Australia at the time (and up to early September 2021) was the Pfizer vaccine, but limited supplies meant that those choosing the Pfizer vaccine had to wait weeks or months to be vaccinated.

Initial risk assessments and decisions about age-based recommendations for the $\mathrm{AZ}$ vaccine in Australia were made at a time when there was almost no local community transmission of COVID-19. Unfortunately, since late June 2021, outbreaks have occurred in multiple states and territories, resulting in prolonged lockdowns of millions of people in New South Wales (NSW), Victoria (VIC), and the Australian Capital Territory (ACT) [14]. Therefore, the risks versus benefits of the AZ vaccine changed dramatically over a few weeks, and those aged $<60$ years have been advised to see a doctor to help them make an individual risk assessment. 
medRxiv preprint doi: https://doi.org/10.1101/2021.09.30.21264337; this version posted October 3, 2021. The copyright holder for this preprint (which was not certified by peer review) is the author/funder, who has granted medRxiv a license to display the preprint in It is made available under a CC-BY-ND 4.0 International license .

110 On 29 June 2021, the Australian Government produced a document on 'Weighing up the potential

111 benefits against the risk of harm from COVID-19 Vaccine AstraZeneca' for clinicians to help patients

112 make informed decisions [15]. The document provides helpful information for each age group such as

113 the risk of TTS versus the number of deaths, intensive care unit (ICU) admissions, and hospitalisations

114 prevented by vaccination under low, medium, and high levels of transmission. However, calculations

115 of risks versus benefits changed rapidly because of many factors, including evolving incidence and CFR

116 of TTS (both in Australia and internationally), changing levels of community transmission, changing

117 age distribution of cases associated with the arrival of the delta variant (the predominant variant in

118 Australia since June 2021), and new data on vaccine effectiveness against the delta variant. These and

119 other factors that influence risk-benefit analysis are likely to continue to evolve at a rapid pace.

120 To address the challenge of providing up-to-date risk-benefit analysis of COVID-19 vaccination, one

121 of the authors (JL) suggested to the Immunisation Coalition

122 (https://www.immunisationcoalition.org.au/) that they support the development of the COVID-19 Risk

123 Calculator (CoRiCal), a set of tools designed to facilitate shared decision making between clinicians

124 and patients. The Immunisation Coalition is a not-for-profit organization with representation from

125 clinical and other professional groups interested in promoting vaccination best practice in Australia.

126 CoRiCal aims to support informed risk assessment by providing relevant and accurate estimates of the

127 risks and benefits of COVID-19 vaccines, taking into account locally relevant factors.

128 This paper describes the first CoRiCal model, focused on risk-benefit analysis of the AZ vaccine. The

129 model was developed using a Bayesian network (BN), which allows the model's inputs to be updated

130 easily as the outbreak situation changes and as scientific evidence evolves. The model aims to provide

131 more precise risk-benefit analysis of $\mathrm{AZ}$ vaccination by comparing the risk of death from vaccine-

132 associated TTS versus the risk death from i) COVID-19 infection, and ii) atypical severe blood clots

133 (cerebral venous sinus thrombosis [CVST] and portal vein thrombosis [PVT]) related to COVID-19

134 infection. The model enables scenario analysis based on age, sex, current transmission intensity,

135 predominant SARS-CoV-2 variant, number of $\mathrm{AZ}$ vaccine doses received, and vaccine effectiveness

136 against symptomatic infection and death. The model could also be extended for outcomes other than 
medRxiv preprint doi: https://doi.org/10.1101/2021.09.30.21264337; this version posted October 3, 2021. The copyright holder for this preprint (which was not certified by peer review) is the author/funder, who has granted medRxiv a license to display the preprint in It is made available under a CC-BY-ND 4.0 International license .

137

138

139

140

141

142

143

144

145

146

147

148

149

150

151

152

153

154

155

156

157

158

159

160

161

death (e.g., ICU admission, long COVID), other vaccines, other adverse events following immunization (AEFI), or adapted for use in other countries.

\section{METHODS}

\subsection{Bayesian networks}

BNs are acyclic graphical models that explicitly represent relationships between variables in terms of conditional probabilities [16]. Variables are represented by nodes, each categorized into several possible states (e.g., yes/no, high/low, age groups). Links (or edges) represent the relationships between nodes and point in the direction from a parent node (independent variable) to a child node (dependent variable) (Figure 1). Nodes are quantified using probability tables that define the probability of a node being in a given state, either based on some prior distribution (for nodes with no parent nodes) or conditional on the states of all parent nodes i.e., conditional probability tables (CPTs).

BN modelling frameworks offer many advantages relevant to the problem at hand. Firstly, BNs provide visual and transparent representation of relationships between variables and the probabilistic assumptions between each variable. The graphical structure enables users to understand how the system has been modelled, clearly shows the underlying assumptions, how model outputs were derived, and enables interactive scenario analysis. Secondly, CPTs can be derived from a range of data formats, allowing relevant data to be integrated from diverse sources including studies, reports, and expert opinion. Thirdly, the probabilistic framework of BNs is well suited to risk analysis where the uncertainty surrounding estimates can be tested through sensitivity analysis for a range of plausible inputs. Finally, model assumptions and CPTs can be updated easily as more information become available or as the situation evolves. Rapid adaptability is particularly important for modelling rapidly evolving situations such as outbreaks.

BNs have been used for a variety of COVID-19 models, including modelling transmission and outbreak response [17, 18], decision making [19], risk analysis [20, 21], risk assessment and contact tracing [22, 
medRxiv preprint doi: https://doi.org/10.1101/2021.09.30.21264337; this version posted October 3, 2021. The copyright holder for this preprint (which was not certified by peer review) is the author/funder, who has granted medRxiv a license to display the preprint in It is made available under a CC-BY-ND 4.0 International license .

162

163

164

165

166

167

168

169

170

171

172

173

174

175

176

177

178

179

180

181

182

183

184

185

186

187

23], interpretation of SARs-CoV-2 test results [24], and predictive diagnosis [25]. However, to our knowledge, BNs have not yet been applied for risk-benefit analysis of COVID-19 vaccines.

\subsection{Model design}

Our BN model structure was based on the best available scientific evidence from multiple sources. Evidence was integrated using facilitated expert elicitation, with subject matter experts (JL, AB, KRS, AKE, CLL, Thrombosis \& Haemostasis Society of Australia and New Zealand [THANZ]) working closely with experienced BN modellers (HJM, KM, CLL). The four subject matter experts included clinicians and researchers with expertise in infectious disease epidemiology, virology, thrombosis, general practice, and public health. The experts defined the scope of the model, key outcome variables of interest, and major predictor variables (inputs) that influenced the outcomes. Experts reviewed published literature and reports to determine whether there was sufficient evidence to include each predictor variable in the model. Predictors were linked to outcomes if there were sufficient evidence and data to quantify the conditional probabilities between them.

Based on the discussions between the experts and modellers, and evidence collected by the experts, a draft BN model structure was derived by the modellers, then reviewed and refined with the team over several iterations of facilitated discussions. To parameterize the model, questionnaires were developed to help experts structure the systematically collected data into CPTs. Variables were not linked if there were only weak quantitative relationships between them because the links would have little impact on model predictions. Data were updated as new evidence became available during the model development process from July-September 2021. External consistency was considered during model design so that predictions were consistent with other commonly used information sources such as the Australian Technical Advisory Group on Immunisation (ATAGI) and the Therapeutic Goods Administration (TGA), e.g., using the same age groups and definitions of low/medium/high community transmission intensity (equivalent to $0.05 \% / 0.45 \% / 5.76 \%$ of population infected over 6 months) [15]. 
medRxiv preprint doi: https://doi.org/10.1101/2021.09.30.21264337; this version posted October 3, 2021. The copyright holder for this preprint (which was not certified by peer review) is the author/funder, who has granted medRxiv a license to display the preprint in It is made available under a CC-BY-ND 4.0 International license.

\subsection{Atypical severe blood clots}

189 TTS is a rare and atypical form of blood clotting associated paradoxical thrombosis and low platelets.

190 TTS is immunologically mediated, and can be trigged by medications (e.g., heparin) or vaccines (e.g., 191 AZ vaccine) [26]. TTS is diagnosed on the basis of clinical criteria and includes atypical severe blood clots such as CVST and splanchnic vein thrombosis (SVT) [27, 28], which have also been reported in

193

194

196

197

198

199

200

201

202

203

204

205

206

207

208

209

210

211

212

COVID-19 patients [29, 30]. CVST and SVT are distinct from the common types of venous thromboembolism such as deep vein thrombosis or pulmonary embolus, or other types of thrombocytopenia and have the highest risk of mortality in this group. SVT includes portal vein thrombosis (PVT), Budd Chiari Syndrome and mesenteric vein thrombosis. The data included in the model focused on PVT as it is the most common type of SVT, and has been specifically reported postCOVID, enabling a direct comparison. Our model therefore focused on comparing the risk of AZ vaccine-associated TTS with the risk of CVST and PVT in COVID-19 patients.

\subsection{Data sources}

While the assumptions and model structure are defined by experts, the CPTs were based on empirical data. Experts compiled evidence from peer-reviewed literature, government websites and reports, and through discussion with external clinical experts (e.g., haematologists regarding the evidence for AZ vaccine- associated TTS, and background rates of CVST and PVT). Official data from Australian authorities were used wherever possible (e.g., local data on AZ vaccine-associated TTS). Otherwise, data were obtained from other robust and publicly available sources (e.g., background rates of CVST and PVT). Data from different sources were harmonised for the CPTs, e.g., summarising data to match the age groups used in the BN. Data analyses were conducted for some variables to convert them into probabilities for the CPTs, e.g., converting incidence of COVID-19 into probability of infection over 6 months for the Intensity of local transmission node. Table 1 [31-40] and Appendix A provide a summary of data sources, model assumptions, and rationale. 
medRxiv preprint doi: https://doi.org/10.1101/2021.09.30.21264337; this version posted October 3, 2021. The copyright holder for this preprint (which was not certified by peer review) is the author/funder, who has granted medRxiv a license to display the preprint in It is made available under a CC-BY-ND 4.0 International license.

213 The model includes default prior distributions for age group (using age distribution of Australia), gender

214 (50\% male, 50\% female), SARS CoV-2 variants (90\% delta, 10\% alpha/ancestral virus), and vaccine 215 coverage (70\% of population received first dose, 35\% received two doses). The prior distributions do 216 not affect the results of scenario analyses, e.g., if delta was selected in the variants node, the model 217 outputs relate to delta only regardless of the prior distribution of variants entered into the model. Prior 218 distributions can be changed to model other scenarios, e.g., different distributions of variants, and different levels of vaccine coverage.

\subsection{Model validation}

222 The final model was assessed by subject matter experts and the modelling team together, to determine if the structure, variables, and assumptions reflected current knowledge and evidence. The model's predictive ability was not validated against a dataset because model parameters were not learned from data. Rather, we validated each section of the model by defining a range of scenarios and manually assessed whether model outputs were consistent with our assumptions. Manual quantitative validations were conducted by a subject matter expert/BN modeller (CLL), a mathematician/statistician/BN modeller (KM) and a biostatistician (MW). Scenarios used for manual validations are provided in Appendix B. All authors evaluated the biological plausibility of estimates, e.g., for COVID-19 patients, the probability of dying from COVID-19 related atypical blood clots should be lower than the total probability of dying from COVID-19.

\subsection{Sensitivity analysis}

234 To determine how often model assumptions need to be updated, sensitivity analysis was conducted for three predictor variables that were considered most likely to change over time. We examined actual changes in the reported incidence of AZ vaccine-associated TTS cases and deaths in Australia in

237 August-September 2021. We also examined i) plausible differences in age-specific CFR for COVID- 
medRxiv preprint doi: https://doi.org/10.1101/2021.09.30.21264337; this version posted October 3, 2021. The copyright holder for this preprint (which was not certified by peer review) is the author/funder, who has granted medRxiv a license to display the preprint in It is made available under a CC-BY-ND 4.0 International license.

23819 in Australia (e.g., if higher CFR with new variants or because of an overwhelmed health system, and

239 ii) plausible reductions in vaccine effectiveness against symptomatic COVID-19 infection and death.

240 Incidence and CFR of vaccine-associated TTS: From July-September 2021, reported incidence of AZ

241 vaccine-associated TTS and related deaths in Australia fluctuated by week because of low numbers.

242 We examined ATAGI reports from 25/8/2021, 1/9/2021, 8/9/2021, and 15/9/2021 [36-39] to determine

243 how fluctuations in data affected our model predictions of age-specific TTS-related deaths over these

244 weeks.

245 Age-specific CFR for COVID-19 in Australia: By 31/8/2021, COVID-19 CFR in Australia were very

246 low for younger age groups, with less than five deaths during the entire pandemic in each male/female

247 subgroups in those aged 0-9, 10-19, 20-29, 30-39, and 40-49 years. We examined changes in CFR if

248 (theoretically) there was one extra death or five extra deaths in each age-sex subgroup, and the potential impact of these changes on model predictions on COVID-19 related deaths.

250

Vaccine effectiveness against symptomatic infection and death: We examined the sensitivity of model outputs to reduced vaccine effectiveness against the delta variant using theoretical assumptions of 5\% and $10 \%$ reduction in effectiveness against both symptomatic infection and death.

\section{RESULTS}

\subsection{Model description}

The final BN structure (Figure 2) synthesises the assumptions regarding probabilistic relationships between variables and outcomes. Table 2 provides a summary of all nodes ( $\mathrm{n} 1$ to $\mathrm{n} 20$ ) and their parent/child relationships. The model was designed to predict five outcomes:

i. Probability of dying from AZ vaccine-associated TTS (n6) - depending on age (n2), $1^{\text {st }}$ or $2^{\text {nd }}$ dose of $\mathrm{AZ}$ vaccine (n1);

ii. Background probability of deaths from CVST and PVT (in those who have not had AZ vaccine or COVID-19 infection) (n7, n8). Estimates were converted to probability of events over 6 
medRxiv preprint doi: https://doi.org/10.1101/2021.09.30.21264337; this version posted October 3, 2021. The copyright holder for this preprint (which was not certified by peer review) is the author/funder, who has granted medRxiv a license to display the preprint in It is made available under a CC-BY-ND 4.0 International license .

Two versions of the model were built using different definitions of the 'AZ vaccine doses (n1)' node: weeks to enable comparison with the probability of vaccine-associated TTS, which generally occurs within 6 weeks of vaccination;

iii. Probability of symptomatic COVID-19 infection - depending on age (n2), sex (n5), variant (n3), intensity of community transmission (n4), vaccine effectiveness against symptomatic infection (n9);

iv. Probability of dying from COVID-19 (n18) - depending on age (n2), sex (n5), variant (n3), intensity of community transmission (n4), vaccine effectiveness against symptomatic infection (n9), vaccine effectiveness against death (n10); and

v. Probability of CVST and PVT deaths (n19, n20) related to COVID-19 infection - depending on $\operatorname{sex}(\mathrm{n} 5)$.

The BN includes five input nodes (orange) that could be used for scenario analysis based on $\mathrm{AZ}$ vaccine doses (n1), age (n2), sex (n5), variant (n3) and intensity of community transmission (n4). Community transmission scenarios were converted to probability of infection over six months to more readily compare the risks versus benefits of vaccination, which is expected to be effective for at least six months. Scenarios were selected based on ATAGI definitions of low/medium/high risk [15], other scenarios that users could relate to (e.g., 1000 cases/day in NSW), and general scenarios that could be adapted to any setting (e.g., $1 \%$ chance of infection over 6 months). The model includes nine intermediate nodes (yellow) where modellers can readily update evidence on incidence of TTS (n6), background incidence of CVST and PVT (n7, n8), relative risk of infection based on age and variant (n11), vaccine effectiveness (n9, n10), and incidence and CFR of COVID-19 related CVST and PVT (n12, n13). to estimate the probability of vaccine-associated TTS with each dose of vaccine. 
medRxiv preprint doi: https://doi.org/10.1101/2021.09.30.21264337; this version posted October 3, 2021. The copyright holder for this preprint (which was not certified by peer review) is the author/funder, who has granted medRxiv a license to display the preprint in It is made available under a CC-BY-ND 4.0 International license.

- Version 2: AZ vaccine doses defined as no doses, received only one dose, and received both doses. This version was used to estimate the probability of deaths in the population based on vaccine coverage rates.

\subsection{Model validation}

A model walk-through indicated that subject matter experts agreed the model structure matched their understanding of the problem space in terms of the relevant predictors and relationships drawn from the external data sources. Independent manual calculations by three authors (CLL, MW, KM) of probabilities of selected outcomes were consistent with model predictions (Appendix B).

A minor anomaly was detected in the model through assessment of biological plausibility. For COVID19 cases in younger age groups (females $<30$ years and males $<10$ years), the estimated probability of dying from COVID-19 was lower than the probability of dying from COVID-19 related atypical severe blood clots. The reason for this anomaly is that data for COVID-19 CFR in Australia were used for the CPTs, and there have been no deaths to date in these age-sex subgroups (Table A3), while data on COVID-19 related atypical blood clots were extracted from a study where data were predominantly sourced from the USA and Europe, where high CFRs could have resulted from an overwhelmed health system during the outbreak. Although the discrepancies in probabilities were extremely low (probability of dying from COVID-19 related atypical blood clots $<0.0002 \%$ higher than dying from COVID-19 itself), the anomaly highlights that the model predictions should be used as broad estimates rather than exact risks.

\subsection{Comparison of estimated deaths prevented from COVID-19 under different scenarios of} community transmission intensity and vaccine coverage, with estimated cases and deaths from $A Z$ vaccine-associated TTS. 
medRxiv preprint doi: https://doi.org/10.1101/2021.09.30.21264337; this version posted October 3, 2021. The copyright holder for this preprint (which was not certified by peer review) is the author/funder, who has granted medRxiv a license to display the preprint in It is made available under a CC-BY-ND 4.0 International license.

314 Model version 2 was used to estimate COVID-19 deaths prevented over 6 months per million population

315 if $70 \%$ had a first dose, and 35\% had two doses. Figures 3a, 3b, and 3c show the estimated deaths

316 prevented for each age group under different levels of community transmission:

- Low transmission (Figure 3a), similar to $1^{\text {st }}$ wave in Australia in 2020, equivalent to $0.05 \%$ of population infected over 6 months.

The model shows that for a million people aged $\geq 70$ years where $70 \%$ have had first dose and $35 \%$ two doses, an estimated 25 deaths would be prevented under low transmission (Fig 3a) versus $>3000$ deaths prevented under high transmission (Fig 3c), with $<1$ expected death from TTS (Fig 3d). In a million people aged 60-69 years with the same vaccine coverage, the model estimates two deaths prevented under low transmission, and 260 deaths prevented under high transmission, with $<1$ expected death from TTS. In contrast, for a million 20-29 year-olds with the same vaccine coverage, $<0.1$ deaths would be prevented under low transmission, $\sim 9$ deaths prevented under high transmission, with $<1$ expected death from TTS. Details on calculations are provided in Appendix C. and PVT) in COVID-19 infected patients

Up to 25/8/2021 in Australia, age-specific incidence of AZ vaccine-associated TTS cases ranged from 16 to 27 per million first doses (Table 1), with an overall CFR of $\sim 5 \%$ ( 6 deaths out of 115 cases). Based on annual background rates of CVST and PVT reported by Kristoffersen et al. [27] and Ageno et al. [28], our model estimated 6-week incidence of 0.38 (age $<20$ years) to 2.69 (age $\geq 70$ years) cases per million, and overall CFR ranging from $7.0 \%$ to $21.6 \%$ from youngest to oldest age groups (Table 
medRxiv preprint doi: https://doi.org/10.1101/2021.09.30.21264337; this version posted October 3, 2021. The copyright holder for this preprint (which was not certified by peer review) is the author/funder, who has granted medRxiv a license to display the preprint in It is made available under a CC-BY-ND 4.0 International license .

341 A7). The background CFR for CVST and PVT (combined) range from 0.03 (age $<20$ years) to 0.58

342 (age $\geq 70$ years) per million over 6 weeks, compared to CFR of 0.83 to 1.40 per million first doses of

343 AZ vaccine depending on age (Table 3).

345 Model assumptions on the incidence and CFR of CVST and PVT in COVID-19 patients were obtained

346 from a retrospective cohort study using linked electronic health records predominantly from the USA

347 and Europe [30] because there were insufficient data from Australia. Model version 1 estimated that overall fatality from atypical severe blood clots (CVST and PVT combined) in COVID-19 patients were 51.1 and 37.3 per 100,000 in males and females, respectively. Figure 4 shows that the probability of developing atypical blood clots in COVID-19 patients was 14-28 times more likely than developing TTS after the first dose of the AZ vaccine, depending on age group and sex (Figure 4, dashed lines). The probability of dying from COVID-19 infection-related atypical blood clots in COVID-19 patients was 58-126 times more likely than dying from TTS after the first dose of AZ vaccine, again depending on age group and sex (Figure 4, solid lines).

355

\subsection{Sensitivity analysis}

\section{Incidence and CFR of $A Z$ vaccine-associated TTS}

ATAGI reports from $25 / 8 / 2021$ to $15 / 9 / 2021$ [36-39] showed minor changes in the incidence of showed that estimated deaths from TTS per million first doses did not change significantly over this time period, and ranged from differences of -0.08 to 0.37 deaths per million (depending on age group) when comparing data from 25/8/2021 with subsequent reports. Therefore, minor fluctuations in CFR from TTS did not have any significant influence on the point estimates of the number deaths at a population level. Because of the small number of TTS cases and deaths in Australia so far, the $95 \%$ confidence intervals (CI) for CFR were wide, ranging from 1.9\% to $12.2 \%$ over the four reports (Table 
medRxiv preprint doi: https://doi.org/10.1101/2021.09.30.21264337; this version posted October 3, 2021. The copyright holder for this preprint (which was not certified by peer review) is the author/funder, who has granted medRxiv a license to display the preprint in It is made available under a CC-BY-ND 4.0 International license .

371 By August 2021, CFR for COVID-19 in Australia was 1.84\% in males and 1.94\% in females. In those 372 aged under 50 years, CFR was $<0.1 \%$ in both sexes (Appendix A). If there was one extra death in each age-sex subgroup during this time, CFR would have increased the most in 60-69 year-olds and the least in 20-29 year-olds, but by less than $0.06 \%$ in any subgroup (Figure 5). The model was most sensitive to changes in the 60-69 year-old age group because of the small case numbers (small denominator). If there were five extra deaths in each age-sex subgroup, CFR would have increased by less than $0.3 \%$ in any subgroup. Therefore, our model was not very sensitive to minor changes in number of reported deaths, and model estimates of deaths per million would have differed by less than $0.06 \%$ or $0.3 \%$ if there were one or five extra deaths in any age-sex subgroup, respectively.

\section{Vaccine effectiveness against symptomatic infection and death}

Our model shows that for a population where $70 \%$ has received first dose and $35 \%$ has received two doses, a theoretical $5 \%$ or $10 \%$ reduction in vaccine effectiveness against the delta variant results in a $7.1 \%$ or $15.1 \%$ increase in estimated deaths, respectively (Table 4 ). Therefore, sensitivity analyses show that model predictions of deaths are much more sensitive to changes in vaccine effectiveness than to changes in incidence and CFR of TTS, or changes in CFR from COVID-19 infection.

\section{DISCUSSION}

391 Our model demonstrates that risk-benefit analysis of the AZ vaccine is complex, and depends on multiple factors including age, sex, vaccine effectiveness, and locally specific factors such as the intensity of community transmission, local incidence and CFR of TTS, and CFR from COVID-19. The model outputs and scenario analysis could facilitate more informed decision making between clinicians and individuals, e.g., by considering age, sex, community transmission, and local data on TTS. The model could also provide decision support at a public health level; if the priors were set to represent the 
medRxiv preprint doi: https://doi.org/10.1101/2021.09.30.21264337; this version posted October 3, 2021. The copyright holder for this preprint (which was not certified by peer review) is the author/funder, who has granted medRxiv a license to display the preprint in It is made available under a CC-BY-ND 4.0 International license.

397

398

399

400

401

402

403

404

405

406

407

408

409

410

411

412

413

414

415

416

417

418

419

420

421

422 times more likely than after the first dose of the AZ vaccine (Figure 4). COVID-19 vaccine.

population in age and sex distribution, vaccination coverage, circulating variants and level of community transmission, the model outputs could be used to estimate deaths or deaths prevented. To our knowledge, this is the first example of the use of Bayesian networks for risk-benefit analysis for a

Our model quantifies the risks (deaths from TTS) versus benefits from vaccination (deaths prevented) for different age groups under different levels of community transmission (Figure 3). While the benefits are significantly greater during higher transmission (especially for older age groups), decisions about vaccination should be based not only on the current level of transmission, but also potential future scenarios. For example, higher transmission will be almost inevitable with lifting of public health restrictions and opening of borders. We presented results for scenarios where $70 \%$ of the population have had first dose and 35\% have had two doses. Other vaccination coverage scenarios can be easily defined in the model priors to assess the current vaccination coverage rates, or future vaccination targets.

To date, the CFR of TTS in Australia has been lower than those reported in other countries $[7,9]$. Although numbers have been small, CFR have remained relatively stable throughout August-September 2021 (Table 3). Possible reasons for the lower CFR in Australia include early shift to Pfizer as the preferred vaccine for those aged $<60$ years; detailed expert review of each case of serious and fatal AEFI (reducing classification error) by state-based committees, ATAGI and TGA; high clinical vigilance of TTS based on lessons learnt from earlier reports from other countries; and clinical guidelines for vaccine providers on early diagnosis and referral of possible TTS cases [41-43]. Our sensitivity analysis showed that fluctuations in observed CFR from TTS had only minor impact on model outputs. Model assumptions can be readily updated if CFR changes significantly in the future. While vaccine-associated TTS of any type can be serious and rarely fatal, mortality for those presenting with atypical severe blood clots (CVST and PVT) in COVID-19 patients are estimated to be 58-126 
medRxiv preprint doi: https://doi.org/10.1101/2021.09.30.21264337; this version posted October 3, 2021. The copyright holder for this preprint (which was not certified by peer review) is the author/funder, who has granted medRxiv a license to display the preprint in It is made available under a CC-BY-ND 4.0 International license .

424 Sensitivity analyses showed that the estimates of COVID-19 related deaths were very sensitive to

425 changes in vaccine effectiveness. Therefore, model assumptions need to be updated to reflect evolving

426 evidence on vaccine effectiveness against current and future variants of the virus, waning immunity

427 over time, and effectiveness of vaccine boosters. From a public health perspective, our findings suggest

428 that a decrease in vaccine effectiveness will likely have important implications on disease burden. In

429 contrast, model outputs were not very sensitive to changes in age-specific CFR for COVID-19, and

430 updates to model assumptions are unlikely to be required unless changes are dramatic.

431

432 We used an innovative and flexible modelling framework which allows model assumptions to be easily 433 changed, either to reflect new data (e.g., vaccine effectiveness), to the evolving situation (e.g., intensity 434 of community transmission, changing CFR from TTS and COVID-19). While the current model is 435 designed to estimate deaths from vaccine versus disease, it could be readily adapted for other outcomes 436 (e.g., ICU admission, long COVID), other adverse events (e.g., immune thrombocytopenia), riskbenefit assessment of other vaccines (e.g., myocarditis/pericarditis from mRNA vaccines), and other types of scenario analysis (e.g., different combinations of vaccine doses and boosters). Our modelling approach also enables the use of multiple sources of data. We have used Australian data wherever possible and international sources if needed (e.g., low number of COVID-19 cases and vaccinations in

441 Australia means that international data on vaccine effectiveness were likely to be more accurate). Our modelling approach therefore provides the potential for countries to develop a locally relevant riskbenefit assessment tool for COVID-19 vaccination even if there are limited local data.

445 Another advantage of BNs is the visual and interactive interface that allows intuitive scenario analysis 446 for users and decision makers. This paper presents results of specific scenarios from our model, but we 447 aim to produce interactive versions of the model and make them freely available on the Immunisation 448 Coalition website (https://www.immunisationcoalition.org.au/). Interactive risk assessment tools for 449 COVID-19 have been developed for estimating the risk of hospitalization and death (e.g., QCOVID tool in United Kingdom [44], COVID-19 risk tools in USA [45] and France [46], predicting clinical outcomes [47], and assessing risk of infection from different activities [48-50]. Some tools were based 
medRxiv preprint doi: https://doi.org/10.1101/2021.09.30.21264337; this version posted October 3, 2021. The copyright holder for this preprint (which was not certified by peer review) is the author/funder, who has granted medRxiv a license to display the preprint in It is made available under a CC-BY-ND 4.0 International license .

452

453

454

455

456

457

458

459

460

461

462

463

464

465

466

467

468

469

470

471

472

473

474

475

476

477 In conclusion, we developed a novel approach to risk-benefit analysis for the AZ vaccine by using an

479

on analysis of millions (e.g., QCOVID [44]) or hundreds of thousands (e.g., ISARIC4C [47]) of medical records. Our modelling approach provides an alternative option of developing risk assessment tools if large datasets are not available, and model inputs need to be sourced from alternative sources. We have not identified any web-based interactive tools that use Bayesian networks for risk-benefit analysis of COVID-19 vaccines for use in clinical or public health settings.

Our results should be interpreted considering the model's limitations. There are uncertainties associated with some of our model inputs, either because of limited data, or the use of data from other countries. As illustrated with the anomaly regarding the risk of dying in younger persons, model outputs should be considered as broad estimates rather than exact risks, but estimates can be improved over time as more data become available. Our model provides population level estimates and does not consider individual risks such as behaviour and comorbidities. We plan to develop future models that include the individual's comorbidities, similar to the QCOVID tool [44] but specific for the Australian context. In the results provided, we have assumed that $100 \%$ of infections were from the delta variant. Assumptions of age distribution of delta cases (if unvaccinated) were obtained from data during the early stages of the delta outbreak in NSW from June 2021. While vaccination rates were relatively low then, older ages had higher vaccine coverage so infection rates for delta may have been underestimated in these groups. Data on CVST and PVT were obtained from studies outside Australia and may not reflect the local experience. The current model focuses on fatalities from COVID-19, TTS, and atypical blood clots, but does not consider other risks (e.g., adverse events) or other benefits (e.g., cases of severe COVID prevented, or broader societal benefits). Our model was not parameterised from any specific datasets, so model outputs could not be directly validated by data. Nevertheless, the model provides a powerful mechanism for complex synthesis of multiple sources of data, and the outputs reflect the latest available knowledge.

adaptable BN modelling framework. Our model enables more precise risk analysis based on demographics, the outbreak situation, local data on vaccine-associated TTS, and the best available 
medRxiv preprint doi: https://doi.org/10.1101/2021.09.30.21264337; this version posted October 3, 2021. The copyright holder for this preprint (which was not certified by peer review) is the author/funder, who has granted medRxiv a license to display the preprint in It is made available under a CC-BY-ND 4.0 International license .

480

481

482

483

484

485

486

487

488

489

490

491

492

493

494

495

496

497

498

499

500

501

502

503

505

506

504 References

international evidence on vaccine effectiveness and atypical blood clots. Although use of the AZ vaccine is expected to gradually decrease in Australia over coming months, the model can be readily adapted for use in other countries or risk-benefit assessment of other vaccines.

\section{Acknowledgements}

We thank Kim Sampson from Immunisation Coalition for facilitating the collaboration between authors, and A/Prof Hassan Valley (La Trobe University, Melbourne, Australia) for contributions to discussions about risk communication and data visualisation. We thank Aapeli Vuorinen (Columbia University) for building the interactive risk assessment tool. Our Bayesian network model was built using GeNIe Modeler (BayesFusion 2019), available free of charge for academic research and teaching use from https://www.bayesfusion.com/. We thank the THANZ Vaccine-induced Immune Thrombotic Thrombocytopenia (VITT) advisory group (in particular A/Prof Vivien Chen, Prof Huyen Tran, A/Prof Jennifer Curnow, Dr Ibrahim Tohidi and Dr Danny Hsu) for their feedback about TTS related data.

\section{Funding}

This research did not receive any specific grant from funding agencies in the public, commercial, or not-for-profit sectors. CLL was supported by an Australian National Health and Medical Research Council (NHMRC) Fellowship (APP1193826).

\section{Conflicts of Interest}

The authors declare that they have no known competing financial interests or personal relationships that could have appeared to influence the work reported in this paper.

1. University of Oxford Oxford vaccine reaches one billion doses released. 2021. https://www.ox.ac.uk/news/2021-07-29-oxford-vaccine-reaches-one-billion-doses-released. 
medRxiv preprint doi: https://doi.org/10.1101/2021.09.30.21264337; this version posted October 3, 2021. The copyright holder for this preprint (which was not certified by peer review) is the author/funder, who has granted medRxiv a license to display the preprint in It is made available under a CC-BY-ND 4.0 International license .

507 2. Merryn Voysey, et al., Safety and efficacy of the ChAdOx1 nCoV-19 vaccine (AZD1222) against SARS-CoV-2: an interim analysis of four randomised controlled trials in Brazil, South Africa, and the UK. The Lancet, 2021. 397(10269): p. 99-111.

510 3. Merryn Voysey, et al., Single-dose administration and the influence of the timing of the booster dose on immunogenicity and efficacy of ChAdOx1 nCoV-19 (AZD1222) vaccine: a pooled analysis of four randomised trials. The Lancet, 2021. 397(10277): p. 881-891.

4. Aziz Sheikh, et al., SARS-CoV-2 Delta VOC in Scotland: demographics, risk of hospital admission, and vaccine effectiveness. The Lancet, 2021. 397(10293): p. 2461-2462.

5. Norwegian Institute of Public Health Norwegian Institute of Public Health's recommendation about AstraZeneca vaccine. 2021. https://www.fhi.no/en/news/2021/astrazeneca-vaccineremoved-from-coronavirus-immunisation-programme-in-norw/. AstraZeneca vaccine in Canada. 2021. https://calgary.ctvnews.ca/alberta-doctors-find-2ndcase-of-blood-clot-linked-to-astrazeneca-vaccine-in-canada-1.5391531.

7. Medicines \& Healthcare products Regulatory Agency, Coronavirus vaccine - weekly summary of Yellow Card reporting. 2021, GOV.UK: United Kingdom. reactions/coronavirus-vaccine-summary-of-yellow-card-reporting. Thrombosis with Thrombocytopenia Syndrome (TTS) and the use of COVID-19 Vaccine AstraZeneca. 2021. https://www.health.gov.au/news/joint-statement-from-atagi-and-thanz-onthrombosis-with-thrombocytopenia-syndrome-tts-and-the-use-of-covid-19-vaccineastrazeneca. 
medRxiv preprint doi: https://doi.org/10.1101/2021.09.30.21264337; this version posted October 3, 2021. The copyright holder for this preprint (which was not certified by peer review) is the author/funder, who has granted medRxiv a license to display the preprint in It is made available under a CC-BY-ND 4.0 International license .

535 11. Australian Government Department of Health ATAGI statement on revised recommendations on the use of COVID-19 Vaccine AstraZeneca, 17 June 2021. 2021. https://www.health.gov.au/news/atagi-statement-on-revised-recommendations-on-the-use-of-

12. Chandini Raina MacIntyre, et al., Thrombosis with Thrombocytopenia Syndrome (TTS) following AstraZeneca ChAdOx1 nCoV-19 (AZD1222) COVID-19 vaccination - A riskbenefit analysis for people < 60 years in Australia. Vaccine, 2021. 39(34): p. 4784-4787.

13. Nicholas Biddle; Ben Edwards; Matthew Gray; Kate Sollis, Vaccine willingness and concerns

14. Australian Government Department of Health COVID-19 summary statistics. Coronavirus

15. Australian Government Department of Health COVID-19 vaccination - Weighing up the

16. Norman Fenton; Martin Neil, Risk Assessment and Decision Analysis with Bayesian Networks. 1 ed. 2012, USA: CBC Press. 524. Modelling. Systems, 2020. 8(2). 
medRxiv preprint doi: https://doi.org/10.1101/2021.09.30.21264337; this version posted October 3, 2021. The copyright holder for this preprint (which was not certified by peer review) is the author/funder, who has granted medRxiv a license to display the preprint in It is made available under a CC-BY-ND 4.0 International license .

563

564

565

566

567

568

569

570

571

572

573

574

575

576

577

578

579

580

581

582

583

584

585

586

587

588

589

Communication Technologies in Tourism 2021. 2021. Cham: Springer International Publishing.

20. Georgina Prodhan and Fenton, Norman, Extending the range of COVID-19 risk factors in a Bayesian network model for personalised risk assessment. medRxiv, 2020: $\mathrm{p}$. 2020.10.20.20215814.

http://medrxiv.org/content/early/2020/10/21/2020.10.20.20215814.abstract.

21. K. Lai and Yanushkevich, S., Machine Reasoning to Assess Pandemics Risks: Case of USS Theodore Roosevelt. ArXiv, 2020. abs/2008.11040. https://arxiv.org/abs/2008.11040.

22. Norman E. Fenton, et al., A Bayesian network model for personalised COVID19 risk assessment and contact tracing. medRxiv, 2021: p. 2020.07.15.20154286. http://medrxiv.org/content/early/2021/01/05/2020.07.15.20154286.abstract.

23. Scott McLachlan, et al., The fundamental limitations of COVID-19 contact tracing methods and how to resolve them with a Bayesian network approach. 2020.

http://dx.doi.org/10.13140/RG.2.2.27042.66243.

24. Yue Wu, et al., Bridging the gaps in test interpretation of SARS-CoV-2 through Bayesian network modelling. Epidemiology and Infection, 2021. 149: p. e166.

25. Rachel Butcher and Fenton, Norman, Extending the range of symptoms in a Bayesian Network for the Predictive Diagnosis of COVID-19. medRxiv, 2020: $\mathrm{p}$.

2020.10.22.20217554.

http://medrxiv.org/content/early/2020/10/26/2020.10.22.20217554.abstract.

26. Edward Burn, et al., Background rates of five thrombosis with thrombocytopenia syndromes of special interest for COVID-19 vaccine safety surveillance: incidence between 2017 and 2019 and patient profiles from 25.4 million people in six European countries. medRxiv, 2021: p. 2021.05.12.21257083.

http://medrxiv.org/content/early/2021/09/17/2021.05.12.21257083.abstract.

27. Espen Saxhaug Kristoffersen, et al., Incidence and Mortality of Cerebral Venous Thrombosis in a Norwegian Population. Stroke, 2020. 51(10): p. 3023-3029. 
medRxiv preprint doi: https://doi.org/10.1101/2021.09.30.21264337; this version posted October 3, 2021. The copyright holder for this preprint (which was not certified by peer review) is the author/funder, who has granted medRxiv a license to display the preprint in It is made available under a CC-BY-ND 4.0 International license.

$59028 . \quad$ W. Ageno, et al., Incidence rates and case fatality rates of portal vein thrombosis and BuddChiari Syndrome. Thromb Haemost, 2017. 117(4): p. 794-800.

592 29. James B. Bussel; Jean M. Connors; Douglas B. Cines; Cynthia E. Dunbar; Laura C. with Thrombocytopenia Syndrome (also termed Vaccine-induced Thrombotic

596 Thrombocytopenia). 2021. https://www.hematology.org/covid-19/vaccine-induced-immunethrombotic-thrombocytopenia.

30. Maxime Taquet, et al., Cerebral venous thrombosis and portal vein thrombosis: $A$ retrospective cohort study of 537,913 COVID-19 cases. EClinicalMedicine, 2021. 39: $\mathrm{p}$.

31. NSW Government NSW COVID-19 cases data. 2021. https://data.nsw.gov.au/nsw-covid-19-

601 data/cases.

602

32. Australian Government Department of Health Cases and deaths by age and sex. Coronavirus (COVID-19) case numbers and statistics, 2021. https://www.health.gov.au/news/healthalerts/novel-coronavirus-2019-ncov-health-alert/coronavirus-covid-19-case-numbers-andstatistics\#cases-and-deaths-by-age-and-sex. System public datasets. 2021. https://www1.health.gov.au/internet/main/publishing.nsf/Content/ohp-pub-datasets.htm. Institute. p. Table S2.5. https://www.doherty.edu.au/uploads/content_doc/DohertyModelling_NationalPlan_and_Adde

613 35. Vaccine Effectiveness Expert Panel (VEEP) VEEP: Vaccine effectiveness table, 16 July 2021. 
medRxiv preprint doi: https://doi.org/10.1101/2021.09.30.21264337; this version posted October 3, 2021. The copyright holder for this preprint (which was not certified by peer review) is the author/funder, who has granted medRxiv a license to display the preprint in It is made available under a CC-BY-ND 4.0 International license .

616 36. Australian Government Department of Health ATAGI update following weekly COVID-19 meeting - 25 August 2021. 2021. https://www.health.gov.au/news/atagi-update-followingweekly-covid-19-meeting-25-august-2021.

619 37. Australian Government Department of Health ATAGI update following weekly COVID-19 meeting - 1 September 2021. 2021. https://www.health.gov.au/news/atagi-update-followingweekly-covid-19-meeting-1-september-2021.

38. Australian Government Department of Health Australian Technical Advisory Group on Immunisation (ATAGI) weekly COVID-19 meeting on 8 September 2021 update. 2021.

39. Australian Government Department of Health ATAGI update following weekly COVID-19 meeting - 15 September 2021. 2021. https://www.health.gov.au/news/atagi-update-followingweekly-covid-19-meeting-15-september-2021.

40. Australian Bureau of Statistics Data downloads - time series spreadsheets. National, state and territory population, 2021. https://www.abs.gov.au/statistics/people/population/national-stateand-territory-population/dec-2020\#data-download.

632 41. Australian Government Department of Health COVID-19 vaccination-Primary care approach to thrombosis with thrombocytopenia syndrome after COVID-19 AstraZeneca vaccine. 2021. https://www.health.gov.au/resources/publications/covid-19-vaccination-

42. Vivien Chen; Jennifer L. Curnow; Huyen Tran; Philip Young-Ill Choi, Australian New thrombocytopenia. Medical Journal of Australia, 2021. 
medRxiv preprint doi: https://doi.org/10.1101/2021.09.30.21264337; this version posted October 3, 2021. The copyright holder for this preprint (which was not certified by peer review) is the author/funder, who has granted medRxiv a license to display the preprint in It is made available under a CC-BY-ND 4.0 International license .

642 44. Ash K. Clift, et al., Living risk prediction algorithm (QCOVID) for risk of hospital admission and mortality from coronavirus 19 in adults: national derivation and validation cohort study. BMJ, 2020. 371: p. m3731.

645 45. Johns Hopkins. COVID-19 Risk Tools. COVID-19 Risk Tooks 2021 [cited 25 September 646 2021]; Available from: https://covid19risktools.com:8443/riskcalculator\#mainbody.

647 46. Viet-Thi Tran, et al., Impact of an interactive web tool on patients' intention to receive COVID-19 vaccination: a before-and-after impact study among patients with chronic conditions in France. BMC Medical Informatics and Decision Making, 2021. 21(1): p. 228.

650 47. ISARIC4C (Coronavirus Clinical Characterisation Consortium). ISARIC4C Mortality Score. ISARIC4C 2021; Available from: https://isaric4c.net.

652 48. National Institute on Ageing. My COVID-19 Visit Risk Calculator. 2021 [cited 25 September 2021]; Available from: https://covidvisitrisk.com/riskscore-english.html.

654 49. The microCOVID Project. microCOVID Project. 2021 [cited 25 September 2021]; Available from: https://www.microcovid.org/about.

656 50. Lifespan; Warren Alpert Medical School of Brown University. MyCOVIDRisk. 2021 [cited 25 September 2021]; Available from: https://mycovidrisk.app. 
Risk-benefit analysis of the AstraZeneca COVID-19 vaccine in Australia using

an adaptable Bayesian network modelling framework

Table 1. Summary of data sources, assumptions, and prior distributions for a Bayesian network to assess risks versus benefits of the AstraZeneca COVID-19 vaccine.

\begin{tabular}{|c|c|c|}
\hline Model inputs & Data sources, assumptions, rationale & Reference \\
\hline $\begin{array}{l}\text { Age distribution of infections } \\
\text { from delta variant }\end{array}$ & $\begin{array}{l}\text { NSW COVID-19 case data from } 1 / 6 / 2021 \text { to } 13 / 8 / 2021 \text { were used to provide estimates of age distribution of infections from delta } \\
\text { variant. Case data published daily by NSW Health, for the following age categories: } 0-19,5 \text {-year age groups from } 20-69 \text { years, and } \\
70+. \text { For cases in the } 0-19 \text { age group, assumed that } 40 \% \text { were aged } 0-9 \text {, and } 60 \% \text { aged } 10-19 \text { (based on age distribution of cases } \\
\text { reported by NNDSS). Date range used was selected to reflect the first } 6 \text { weeks of delta outbreak, when vaccination coverage was } \\
\text { relatively low. No significant change in age distribution of cases to } 29 / 8 / 2021 \text {. See Appendix A, Table A1. }\end{array}$ & 31,32 \\
\hline $\begin{array}{l}\text { Age distribution of infections } \\
\text { from alpha/wild variants }\end{array}$ & $\begin{array}{l}\text { COVID-19 cases reported in Australia from January to December } 2020 \text { were used to provide estimates of age distribution from } \\
\text { alpha/wild variants. Data sourced from National Notifiable Diseases Surveillance System. See Appendix A, Table A2. }\end{array}$ & 14,33 \\
\hline $\begin{array}{l}\text { Case fatality rates of COVID- } \\
19 \text { cases }\end{array}$ & $\begin{array}{l}\text { COVID-19 cases reported in Australia from January } 2020 \text { to 13/8/2021 were used to provide estimates of age-specific case } \\
\text { fatality. Data sourced from National Notifiable Diseases Surveillance System. See Appendix A, Table A3. }\end{array}$ & 14,33 \\
\hline \multirow{3}{*}{$\begin{array}{l}\text { Community transmission } \\
\text { levels }\end{array}$} & Chance of infection over 6 months calculated for different levels of community transmission. See Appendix A, Table A4. & 15 \\
\hline & $\begin{array}{l}\text { Definitions of low, medium, and high transmission as defined by ATAGI document 'Weighing up the potential benefits and risk of } \\
\text { harm from COVID-19 Vaccine AstraZeneca'. Low - similar to first wave in Australia (equivalent to 0.05\% of population infected } \\
\text { over } 6 \text { months). Medium - similar to second wave in VIC in } 2020 \text { (equivalent to } 0.045 \% \text { of population infected over } 6 \text { months). } \\
\text { High - similar to Europe in January } 2021 \text { (equivalent to } 5.76 \% \text { of population infected over } 6 \text { months). }\end{array}$ & \\
\hline & $\begin{array}{l}\text { Also included transmission scenarios equivalent to: zero transmission; } 1 \% \text { and } 2 \% \text { chance of infection over } 6 \text { months; } 200 \\
\text { cases/day and } 1000 \text { cases/day in NSW; } 1000 \text { cases/day in VIC; } 1000 \text { cases/day in QLD. Other transmission levels can be added to } \\
\text { model. }\end{array}$ & \\
\hline $\begin{array}{l}\text { Chance of infection by age } \\
\text { group }\end{array}$ & $\begin{array}{l}\text { Chance of infection differed between age groups and by variants. Calculated chance of infection by age group if overall } \\
\text { community transmission of } 1 \% \text {. Calculations based on age distribution of infections from delta and alpha/wild variants, and age } \\
\text { distribution of Australian population. See Appendix A, Table A5. }\end{array}$ & \\
\hline $\begin{array}{l}\text { Vaccine effectiveness against } \\
\text { symptomatic infection }\end{array}$ & $\begin{array}{l}\text { Delta variant (ATAGI recommended data used in Doherty transmission model): } \\
\text { - } \quad 33 \% \text { effective after } 1^{\text {st }} \text { dose } \\
\text { - } \quad 61 \% \text { effective after } 2^{\text {nd }} \text { dose } \\
\text { (Note: Public Health England estimates effectiveness of } 45 \% \text { after } 1^{\text {st }} \text { dose, and } 70 \% \text { after } 2^{\text {nd }} \text { dose) }\end{array}$ & 34,35 \\
\hline
\end{tabular}


Alpha variant (from Vaccine effectiveness Expert Panel, Public Health England):

- $60 \%$ effective after $1^{\text {st }}$ dose

- $80 \%$ effective after $2^{\text {nd }}$ dose

Vaccine effectiveness against death

Delta variant (ATAGI recommended data used in Doherty transmission model):

- $69 \%$ effective after $1^{\text {st }}$ dose

- $\quad 90 \%$ effective after $2^{\text {nd }}$ dose

(Note: Public Health England estimates effectiveness of $80 \%$ after $1^{\text {st }}$ dose, and $95 \%$ after $2^{\text {nd }}$ dose).

Alpha variant (from Vaccine effectiveness Expert Panel, Public Health England):

- $80 \%$ effective after $1^{\text {st }}$ dose

- $\quad 95 \%$ effective after $2^{\text {nd }}$ dose

Thrombosis and

Thromobcytopenia Syndrome

(TTS) after AZ vaccine
Model uses data reported by ATAGI update following weekly COVID-19 meeting on 25/8/2021.

Estimated rate per $100,0001^{\text {st }}$ dose of AZ vaccinations:

- Age <50: 2.5

- Age 50-59: 2.7

- $\quad$ Age 60-69: 1.6

- $\quad$ Age 70-79: 2.1

- $\quad$ Age $\geq 80$ : $\quad 1.6$

- For age $\geq 70$ in model, used rate of 1.85 (average of rates for $70-79$ and $\geq 80$ ).

Estimated rate per 100,000 after $2^{\text {nd }}$ dose of AZ vaccinations: 0.18 per 100,000 (no age specific rates available).

Case fatality rate in Australia 5\% (noting that higher rates reported in UK 18\%).

For sensitivity analysis, data from ATAGI reports on 1/9/2021, 8/9/2021, and 15/9/2021 were used.

\section{Background rates of atypical venous thrombotic disorders}

\section{Background rates (in population not infected with and not vaccinated for COVID-19) of atypical venous thrombotic disorder (CVST 27,28} and PVT) over 6 weeks were calculated for each age group to provide a comparison with chance of TTS after AZ vaccine.

CVST data from Kristoffersen et al.

- Age-specific rates per million population per year:

$$
\begin{array}{ll}
\circ & \text { Age <20: } 10.8 \\
\circ & \text { Age 20-49: } 18.0 \\
\circ & \text { Age 50-69: } 21.1 \\
\circ & \text { Age } \geq 70: 20.7
\end{array}
$$

- $\quad$ Case fatality of $7 \%$ for all age groups.

- Assumed equal rates in males and females. 
PVT data from Ageno et al.

- Age-specific rates per million population per year:
$\circ \quad$ Age <20: 0
○ Age 20-29: 5.5
○ Age 30-39: 7.25
○ Age 40-49: 15.75
Age 50-59: 25.5
- Age 60-69: 49.5
○ Age $\geq 70: 55.125$

- Case fatality of $27.2 \%$ for all age groups.

- Assumed equal rates in males and females.

Atypical venous thrombotic disorders associated with COVID-19 infection

\section{Rates}

- Cases per million COVID-19 infections:

$$
\text { ○ Male: } 28.87
$$

o Female: 54.20

- Case fatality $17.4 \%$ for both sexes.

- Assumed same rates for all age groups.

PVT:

- Cases per million COVID-19 infections:

- Male: 483

- Female: 318

- Case fatality $19.9 \%$ for both sexes.

- Assumed same rates for all age groups.

Prior distributions

Assumptions

Age distribution of Australian

Australian Bureau of Statistics. National population estimates, December 2020. See Appendix A, Table A6.

40

population

Gender distribution of

Australian population

\begin{tabular}{ll}
\hline Variants & $90 \%$ delta, $10 \%$ alpha/wild \\
\hline Vaccine coverage & $70 \%$ received $1^{\text {st }}$ dose, $35 \%$ received $2^{\text {nd }}$ dose
\end{tabular}

ATAGI=Australian Technical Advisory Group on Immunisation; CVST=Cerebral venous sinus thrombosis; PVT=Portal vein thrombosis. *Note that prior distributions do not affect results of scenario analysis but enables the model to provide population-level estimates. Assumptions can be changed as the situation evolves. 
Table 2. Summary of nodes and relationships between nodes in a Bayesian network for assessing risks versus benefits of the AstraZeneca COVID-19 vaccine.

\begin{tabular}{|c|c|c|c|c|c|}
\hline Node name (number) & Description & Potential values & Node type & Parent nodes & Child nodes \\
\hline AZ vaccine doses (n1) & $\begin{array}{l}\text { Version 1: Vaccine dose number } \\
\text { Version 2: Vaccine coverage in population }\end{array}$ & $\begin{array}{l}\text { Version 1: None, } 1^{\text {st }} \text { dose, } 2^{\text {nd }} \text { dose } \\
\text { Version 2: None, one dose only, two doses }\end{array}$ & Input & $\begin{array}{l}\text { N/A - Default priors: } 30 \% \text { unvaccinated, } 35 \% \\
\text { had one dose only, } 35 \% \text { had two doses. }\end{array}$ & $\mathrm{n} 6, \mathrm{n} 10, \mathrm{n9}$ \\
\hline Age group (n2) & Age group & $\begin{array}{l}0-9,10-19,20-29,30-39,40-49,50-59,60- \\
69,70+\end{array}$ & Input & $\begin{array}{l}\text { N/A - Default priors: population distribution of } \\
\text { Australia }\end{array}$ & $\begin{array}{l}\text { n6, n7, n8, } \\
n 11, n 18\end{array}$ \\
\hline SARS CoV-2 variant (n3) & $\begin{array}{l}\text { Dominant SARS CoV-2 variant(s) currently } \\
\text { circulating }\end{array}$ & Alpha/wild, Delta & Input & $\begin{array}{l}\text { N/A - Default priors: } 5 \% \text { Alpha/wild and } 95 \% \\
\text { Delta }\end{array}$ & n9, n10, n11 \\
\hline $\begin{array}{l}\text { Intensity of community } \\
\text { transmission - } \mathrm{x} \% \text { over } 6 \\
\text { months }(\mathrm{n} 4)\end{array}$ & $\begin{array}{l}\text { Probability of infection over 6-months } \\
\text { based on different levels of community } \\
\text { transmission }\end{array}$ & $\begin{array}{l}\text { None, } \\
\text { ATAGI definitions of low, med, high, } \\
1 \%, 2 \% \text {, } \\
\text { NSW } 200 \text { cases/day, NSW } 1000 \text { cases/day, } \\
\text { Vic } 1000 \text { cases/day, QLD } 1000 \text { cases/day }\end{array}$ & Input & N/A - Defaults to uniform distribution & n14 \\
\hline Sex (n5) & Sex & Male, female & Input & N/A - Defaults to uniform distribution & $\mathrm{n} 12, \mathrm{n} 13, \mathrm{n} 18$ \\
\hline Vaccine-associated TTS (n6) & Probability of AZ vaccine-associated TTS & Yes, no & Intermediate & AZ vaccine doses (n1), Age group (n2) & n15 \\
\hline CVST over 6 weeks (n7) & $\begin{array}{l}\text { Probability of developing CVST over } 6 \\
\text { weeks }\end{array}$ & Yes, no & Intermediate & Age group (n2) & n16 \\
\hline PVT over 6 weeks (n8) & Probability of developing PVT over 6 weeks & Yes, no & Intermediate & Age group (n2) & n17 \\
\hline $\begin{array}{l}\text { Vaccine effectiveness against } \\
\text { symptomatic infection ( } \mathrm{n} 9)\end{array}$ & $\begin{array}{l}\text { Effectiveness of the vaccine at preventing } \\
\text { symptomatic SARS CoV-2 infection }\end{array}$ & Yes, no & Intermediate & AZ vaccine doses (n1), SARS CoV-2 variant (n3) & n14 \\
\hline $\begin{array}{l}\text { Vaccine effectiveness against } \\
\text { death }(\mathrm{n} 10)\end{array}$ & $\begin{array}{l}\text { Effectiveness of the vaccine at preventing } \\
\text { deaths from symptomatic SARS CoV-2 } \\
\text { infection }\end{array}$ & Yes, no & Intermediate & AZ vaccine doses (n1), SARS CoV-2 variant (n3) & n18 \\
\hline $\begin{array}{l}\text { Relative risk of infection } \\
\text { depending on age and variant } \\
\text { (n11) }\end{array}$ & $\begin{array}{l}\text { Relative risk of COVID-19 infection } \\
\text { depending on age and variant }\end{array}$ & Yes, no & Intermediate & Age group (n2), SARS CoV-2 variant (n3) & n14 \\
\hline $\begin{array}{l}\text { CVST from Covid infection } \\
\text { (n12) }\end{array}$ & $\begin{array}{l}\text { Probability of developing CVST if develops } \\
\text { symptomatic COVID-19 }\end{array}$ & Yes, no & Intermediate & $\begin{array}{l}\text { Sex (n5), Risk of symptomatic infection under } \\
\text { current transmission and vaccination status } \\
\text { (n12) }\end{array}$ & $\mathrm{n} 20$ \\
\hline
\end{tabular}




\begin{tabular}{|c|c|c|c|c|c|}
\hline $\begin{array}{l}\text { PVT from Covid infection } \\
\text { (n13) }\end{array}$ & $\begin{array}{l}\text { Probability of developing PVT if develops } \\
\text { symptomatic COVID-19 }\end{array}$ & Yes, no & Intermediate & $\begin{array}{l}\text { Sex (n5), Risk of symptomatic infection under } \\
\text { current transmission and vaccination status } \\
\text { (n12) }\end{array}$ & N/A \\
\hline $\begin{array}{l}\text { Risk of symptomatic infection } \\
\text { under current transmission } \\
\text { and vaccination status (n14) }\end{array}$ & Probability of symptomatic COVID-19 & Yes, no & Intermediate & $\begin{array}{l}\text { Intensity of community transmission - } x \% \text { over } \\
6 \text { months ( } 44) \text {, Vaccine effectiveness against } \\
\text { symptomatic infection ( } n 9 \text { ), Relative risk of } \\
\text { infection depending on age and variant (n11) }\end{array}$ & n19 \\
\hline Die from CVST (n16) & $\begin{array}{l}\text { Probability of dying from CVST } \\
\text { (background rate in those who have not } \\
\text { had vaccine or infection) }\end{array}$ & Yes, no & Outcome & CVST over 6 weeks (n7) & N/A \\
\hline Die from PVT (n17) & $\begin{array}{l}\text { Probability of dying from PVT (background } \\
\text { rate in those who have not had vaccine or } \\
\text { infection) }\end{array}$ & Yes, no & Outcome & PVT over 6 weeks (n8) & N/A \\
\hline $\begin{array}{l}\text { Die from Covid-related CVST } \\
\text { (n19) }\end{array}$ & $\begin{array}{l}\text { Probability of dying from COVID-19 related } \\
\text { CVST }\end{array}$ & Yes, no & Outcome & CVST from SARS COV-2 infection (n13) & N/A \\
\hline $\begin{array}{l}\text { Die from Covid-related PVT } \\
\text { (n20) }\end{array}$ & $\begin{array}{l}\text { Probability of dying from COVID-19 related } \\
\text { PVT }\end{array}$ & Yes, no & Outcome & PVT from SARS COV-2 infection (n14) & N/A \\
\hline
\end{tabular}


Table 3. Evolving evidence on incidence and case-fatality rate (CFR) of vaccine-associated Thrombosis with Thrombocytopenia Syndrome (TTS) in Australia in AugustSeptember 2021, and influence on estimated TTS-related deaths by age group.

\begin{tabular}{|c|c|c|c|c|c|c|c|c|c|c|c|c|c|c|c|}
\hline \multirow[t]{2}{*}{$\begin{array}{l}\text { Age } \\
\text { group } \\
\text { (years) }\end{array}$} & \multicolumn{4}{|c|}{$\begin{array}{c}\text { Estimated incidence of TTS per million } \\
1^{\text {st }} \text { doses of } A Z \text { vaccinations } \mathrm{s}^{\mathrm{a}}\end{array}$} & \multicolumn{4}{|c|}{$\begin{array}{l}\text { Cases }^{b} \text {, deaths } \\
1^{\text {st }} \text {, and } \text { CFR }^{c} \text { from of } A Z \text { vaccinations }\end{array}$} & \multicolumn{4}{|c|}{$\begin{array}{c}\text { Estimated deaths per million } \\
1^{\text {st }} \text { doses of } A Z \text { vaccinations based on observed } \\
\text { CFR to date }\end{array}$} & \multicolumn{3}{|c|}{$\begin{array}{l}\text { Difference in estimated deaths per } \\
\text { million compared to } 25 / 8 / 2021\end{array}$} \\
\hline & $25 / 8 / 2021$ & $1 / 9 / 2021$ & $8 / 9 / 2021$ & $15 / 9 / 21$ & $25 / 8 / 2021$ & $1 / 9 / 2021$ & $8 / 9 / 2021$ & $15 / 9 / 21$ & $25 / 8 / 2021$ & $1 / 9 / 2021$ & $8 / 9 / 2021$ & $15 / 9 / 21$ & $1 / 9 / 2021$ & $8 / 9 / 2021$ & $15 / 9 / 2021$ \\
\hline$<50$ & 25 & 22 & 20 & 18 & \multirow{5}{*}{$\begin{array}{l}\text { Cases }=115 \\
\text { Deaths }=6 \\
\text { CFR }=5.2 \% \\
(95 \% \mathrm{Cl} 1.9- \\
11.0 \%)\end{array}$} & \multirow{5}{*}{$\begin{array}{l}\text { Cases }=125 \\
\text { Deaths }=8 \\
\text { CFR }=6.4 \% \\
(95 \% \mathrm{Cl} 2.8- \\
12.2 \%)\end{array}$} & \multirow{5}{*}{$\begin{array}{l}\text { Cases }=132 \\
\text { Deaths }=8 \\
\text { CFR }=6.1 \% \\
(95 \% \mathrm{Cl} 2.7- \\
11.6 \%)\end{array}$} & \multirow{5}{*}{$\begin{array}{l}\text { Cases }=134 \\
\text { Deaths }=8 \\
\mathrm{CFR}=6.0 \% \\
(95 \% \mathrm{Cl} 2.6- \\
11.4 \%)\end{array}$} & 1.30 & 1.41 & 1.22 & 1.08 & 0.11 & -0.08 & -0.22 \\
\hline $50-59$ & 27 & 26 & 29 & 28 & & & & & 1.40 & 1.66 & 1.77 & 1.68 & 0.26 & 0.37 & 0.28 \\
\hline $60-69$ & 16 & 17 & 16 & 16 & & & & & 0.83 & 1.09 & 0.98 & 0.96 & 0.26 & 0.14 & 0.13 \\
\hline $70-79$ & 21 & 21 & 20 & 20 & & & & & 1.09 & 1.34 & 1.22 & 1.20 & 0.25 & 0.13 & 0.11 \\
\hline$\geq 80$ & 16 & 16 & 17 & 19 & & & & & 0.83 & 1.02 & 1.04 & 1.14 & 0.19 & 0.21 & 0.31 \\
\hline
\end{tabular}

a Incidence of TTS in Australia reported by ATAGI.

${ }^{\mathrm{b} C u m u l a t i v e}$ cases and deaths to date in Australia, all ages.

CFR=Case fatality rate for all ages combined, and binomial exact 95\% confidence interval.

Table 4. Impact of theoretical reduction in vaccine effectiveness against delta variant on estimated deaths, assuming $70 \%$ of population had first dose, and $35 \%$ had two doses.

\begin{tabular}{|c|c|c|c|}
\hline Delta variant & $\begin{array}{l}\text { Current model } \\
\text { assumptions }\end{array}$ & $\begin{array}{l}\text { If } 5 \% \text { less } \\
\text { effective }\end{array}$ & $\begin{array}{l}\text { If } 10 \% \text { less } \\
\text { effective }\end{array}$ \\
\hline \multicolumn{4}{|c|}{ Vaccine effectiveness against symptomatic infection } \\
\hline after & $33 \%$ & $28 \%$ & $23 \%$ \\
\hline $\begin{array}{l}\text { - } 1^{\text {st }} \text { dose } \\
\text { - } \quad 2^{\text {nd }} \text { dose }\end{array}$ & $61 \%$ & $56 \%$ & $51 \%$ \\
\hline \multicolumn{4}{|l|}{ Vaccine effectiveness against death after } \\
\hline - $\quad 1^{\text {st }}$ dose & $69 \%$ & $64 \%$ & $59 \%$ \\
\hline - $\quad 2^{\text {nd }}$ dose & $90 \%$ & $85 \%$ & $80 \%$ \\
\hline $\begin{array}{l}\text { \% Increase in estimated deaths compared to } \\
\text { model assumptions of vaccine effectiveness }\end{array}$ & $\mathrm{N} / \mathrm{A}$ & $7.1 \%$ & $15.1 \%$ \\
\hline
\end{tabular}


a)

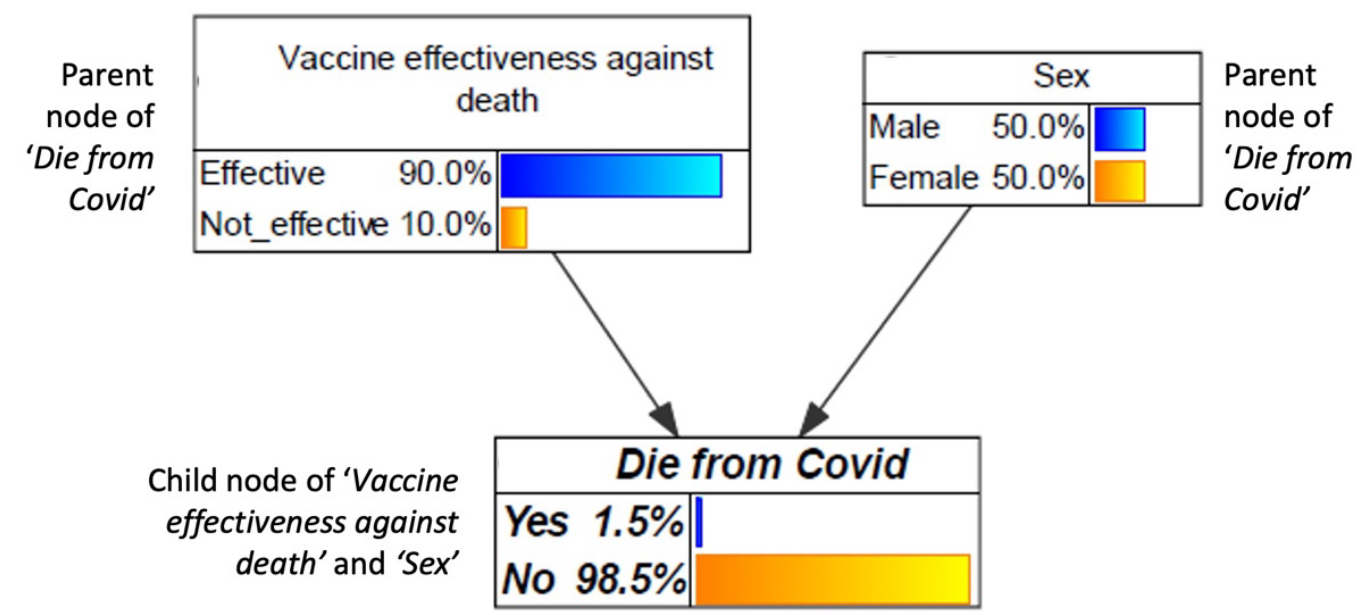

b)

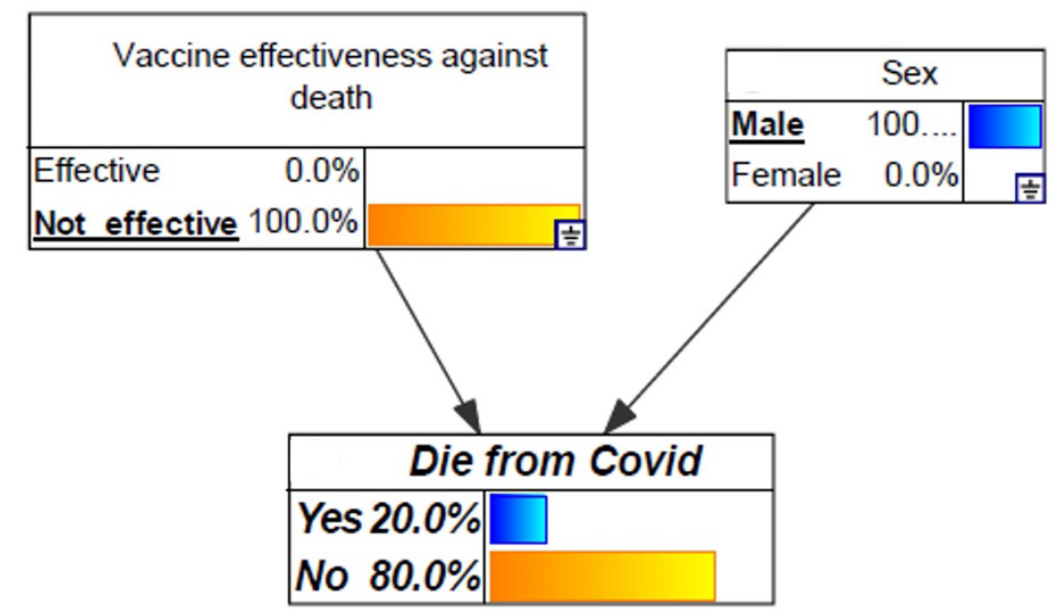

\begin{tabular}{|l|l|c|c|c|c|}
\hline \multicolumn{2}{|c|}{ Vaccine effectives } & \multicolumn{2}{c|}{ Effective } & \multicolumn{2}{c|}{ Not effective } \\
\hline \multicolumn{2}{|c|}{ Sex } & Male & Female & Male & Female \\
\hline $\begin{array}{l}\text { Die from } \\
\text { Covid }\end{array}$ & Yes & $0 \%$ & $0 \%$ & $20 \%$ & $10 \%$ \\
\cline { 2 - 6 } & No & $100 \%$ & $100 \%$ & $80 \%$ & $90 \%$ \\
\hline
\end{tabular}

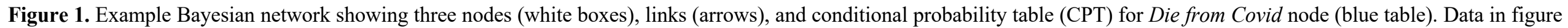

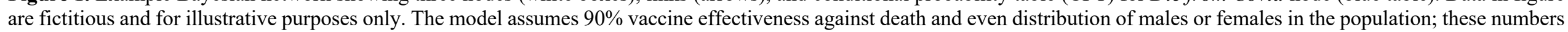

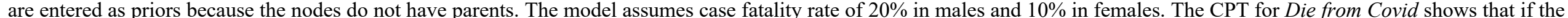

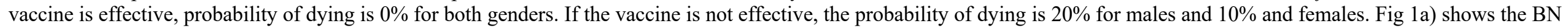



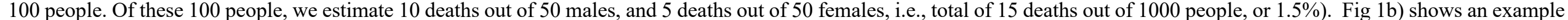

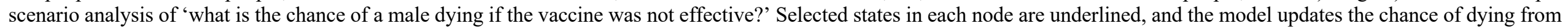
COVID to $20 \%$ under this scenario. 
medRxiv preprint doi: https://doi.org/10.1101/2021.09.30.21264337; this version posted October 3, 2021. The copyright holder for this preprint (which was not certified by peer review) is the author/funder, who has granted medRxiv a license to display the preprint in perpetuity.

It is made available under a CC-BY-ND 4.0 International license.

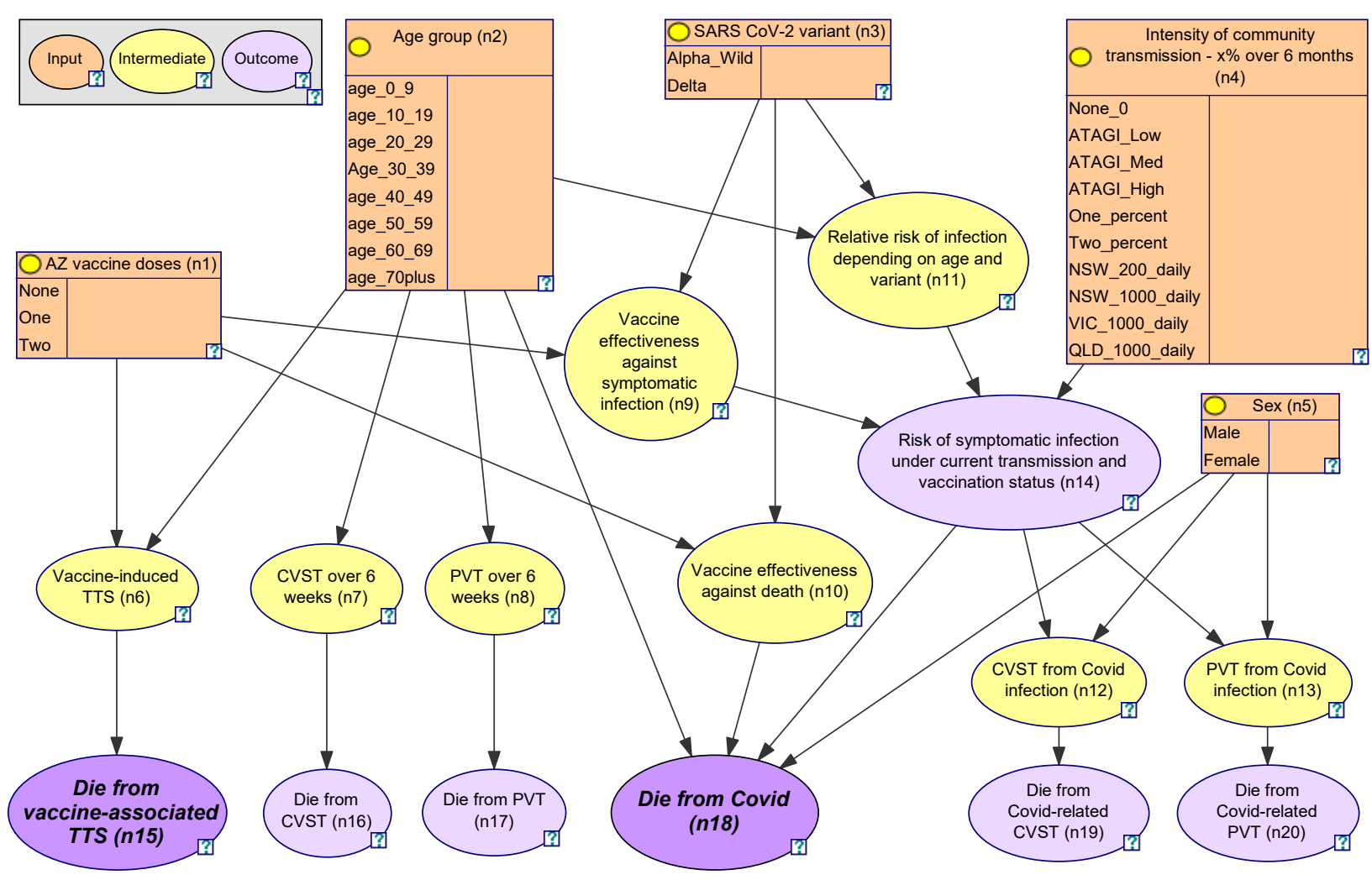

Figure 2. Bayesian network for assessing risks versus benefits of the AstraZeneca COVID-19 vaccine. 
medRxiv preprint doi: https://doi.org/10.1101/2021.09.30.21264337; this version posted October 3, 2021. The copyright holder for this preprint (which was not certified by peer review) is the author/funder, who has granted medRxiv a license to display the preprint in It is made available under a CC-BY-ND 4.0 International license.

a)



Age groups (years)

c)

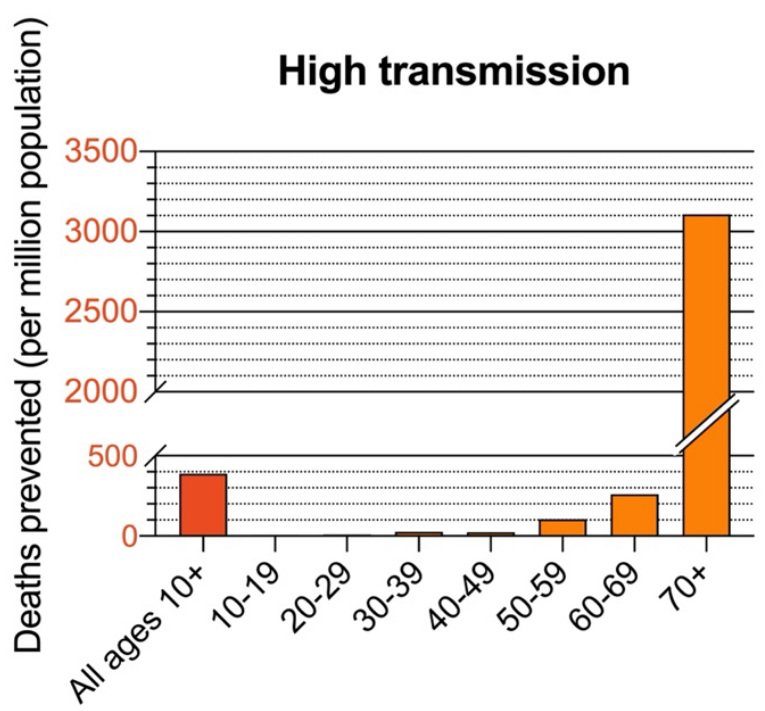

Age groups (years) b)



Age groups (years)

d)

Deaths from AZ vaccine-induced TTS

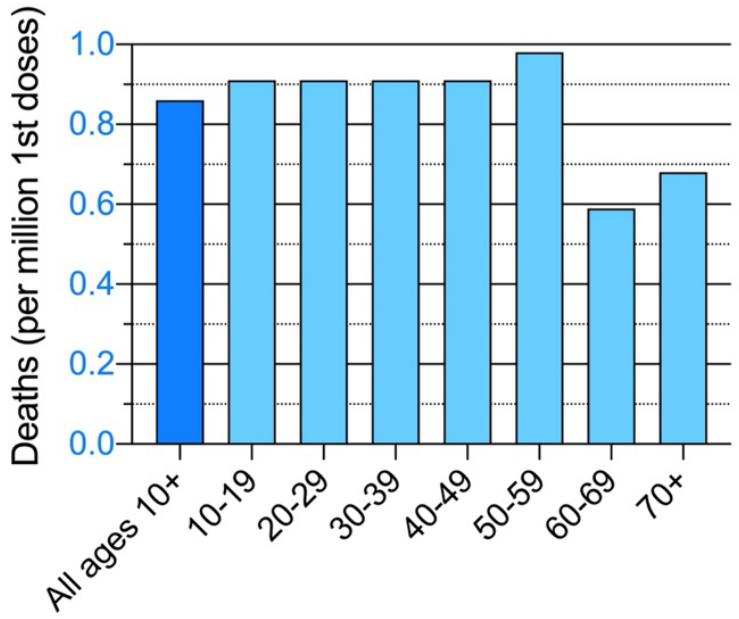

Age groups (years)

Figure 3. Estimated COVID-19 deaths prevented over 6 months per million population of each age group if $70 \%$ had first dose, and 35\% had two doses of AZ vaccine under a) low, b) medium, and c) high levels of community transmission; and d) estimated deaths from AZ vaccine-associated TTS if $70 \%$ of the population had first dose, and $35 \%$ had two doses. (Note the large variations in scale in y-axes between each graph). 


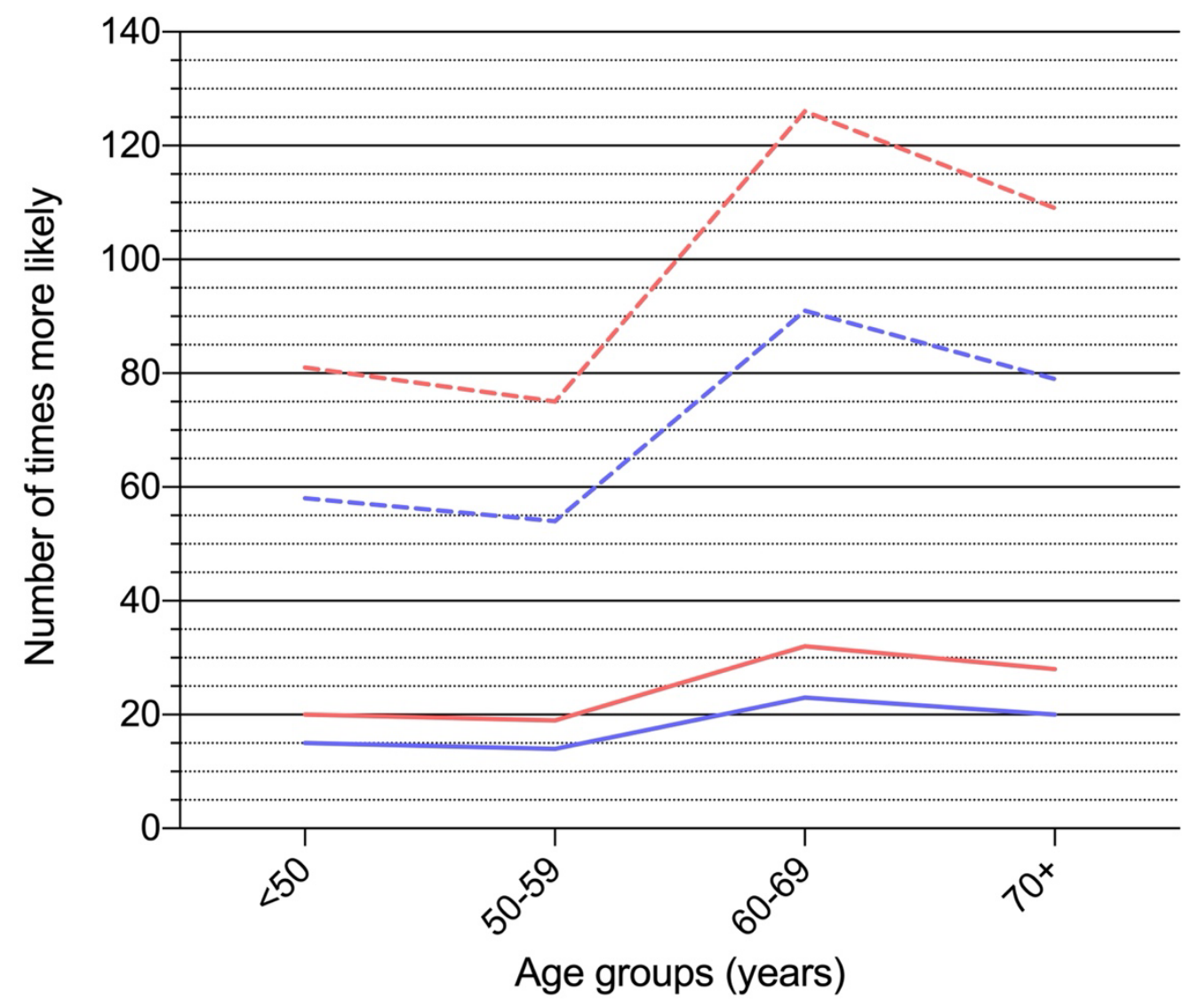

-- To develop atypical blood clots from COVID-19 infection than AZ vaccineassociated TTS (male)

-- To develop atypical blood clots from COVID-19 infection than AZ vaccineassociated TTS (female)

- To die from atypical blood clots from COVID-19 infection than AZ vaccineassociated TTS (male)

- To die from atypical blood clots from COVID-19 infection than $A Z$ vaccineassociated TTS (female)

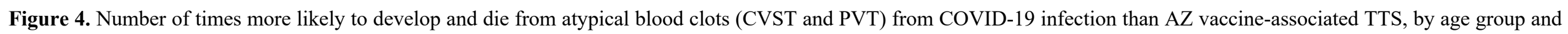
sex. 
a)

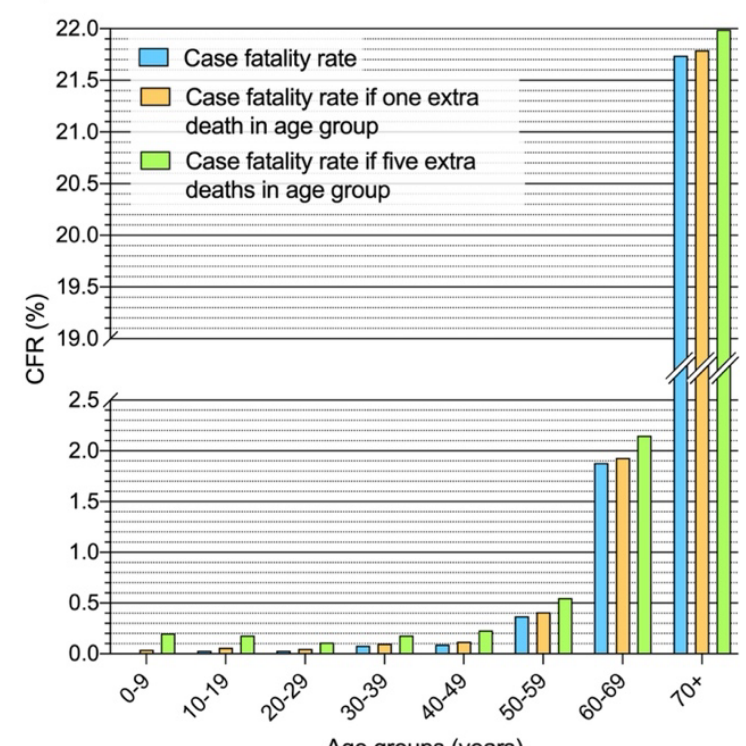

b)



C) Absolute difference in CFR if extra deaths in age group

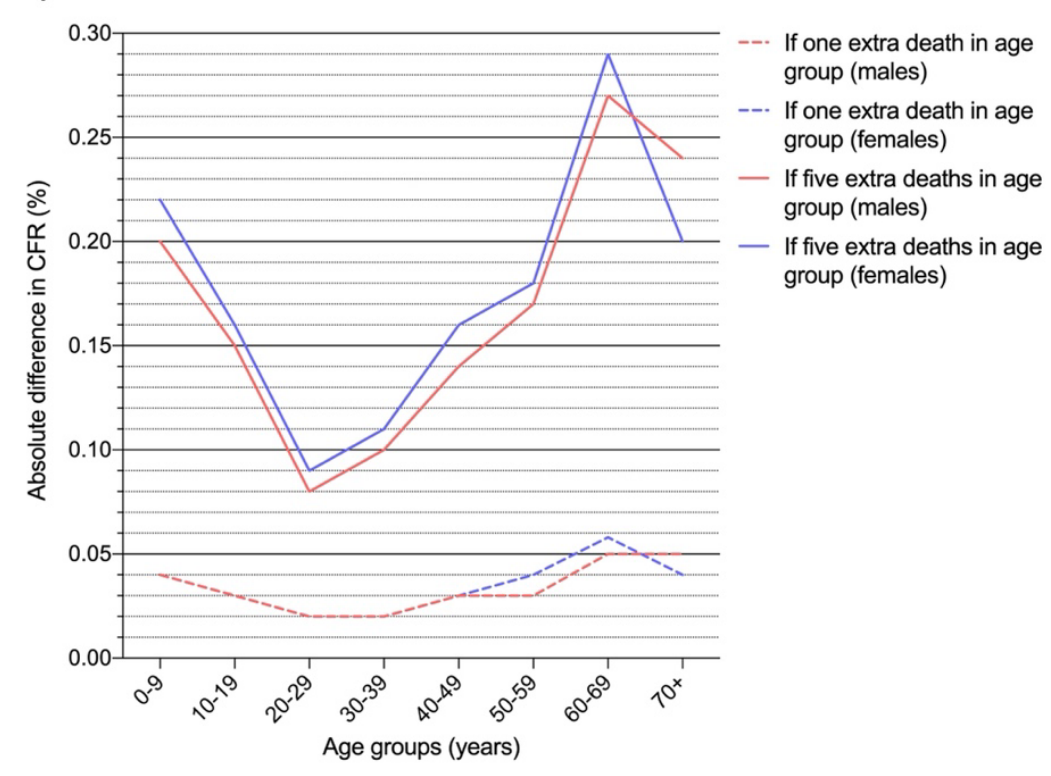

Figure 5. Change in age-sex specific case fatality rate for COVID-19 if one or five extra deaths in each subgroup: a) CFR in males, b) CFR in females, c) absolute difference in CFR if one or five extra deaths. (Based on COVID-19 cases and deaths in Australia by 31/8/2021). 